\title{
Metabolism of Valine and Isoleucine in Growing Rats at Various Dietary Protein Levels
}

\author{
Hideyuki TanaKa, Tsutomu Fukushima, Yasuo NaKatomi \\ and Masaji Ogura \\ Department of Agricultural Chemistry, Faculty of Agriculture, \\ Utsunomiya University, Mine-350, Utsunomiya 321, Japan \\ Received October 15, 1987
}

\begin{abstract}
The metabolic fate of the carbon skeletons of $\mathrm{L}_{-}\left[\mathrm{U}_{-}{ }^{14} \mathrm{C}\right]$ valine and $\mathrm{L}-\left[\mathrm{U}-{ }^{14} \mathrm{C}\right]$ isoleucine was investigated in growing rats fed with diets containing different percentages of protein calories $(0,5$, 10,15 and $30 \mathrm{PC} \%$ ) at $4,100 \mathrm{kcal}$ of metabolizable energy per $\mathrm{kg}$ of diet. The nutritional significance of the metabolism of the branched chain amino acids is discussed.

The incorporation of ${ }^{14} \mathrm{C}$ into the body protein from ${ }^{14} \mathrm{C}$-valine or isoleucine was about $80 \%$ of the injected dose in the 0 and $5 \mathrm{PC} \%$ groups, but it decreased with the increasing level of dietary protein from 10 to $30 \mathrm{PC} \%$. The expired ${ }^{14} \mathrm{CO}_{2}$ production from ${ }^{14} \mathrm{C}$-isoleucine was depressed with reducing $\mathrm{PC} \%$, and then increased with higher $\mathrm{PC} \%$ in the diets, showing a break point at $5 \mathrm{PC} \%$, whereas a linear increase in ${ }^{14} \mathrm{CO}_{2}$ production was observed for labeled valine with increasing of the dietary protein level. The conversion of the carbon skeleton of ${ }^{14} \mathrm{C}$-valine into the body lipid was the lowest among the branched chain amino acids, reflecting its glycogenic property.

These results indicate that the metabolic response of the carbon skeleton of valine and isoleucine to dietary protein level changes at around $10 \mathrm{PC} \%$, at which the growth rate and body protein retention reached approximate maxima.
\end{abstract}

The branched chain amino acids, valine, isoleucine and leucine, are required for growth in rats and other animals. These three amino acids are catabolized to a great extent by extrahepatic tissues such as the pancreas, kidney and muscle. "The first step in the degradation of branched chain amino acids is a transamination reaction, and the corresponding keto acids that are produced lead finally to different intermediates of the tricarboxylic acid cycle. The carbon skeleton of valine is degraded to succinyl-CoA, that of isoleucine yields succinyl-CoA and acetyl-CoA, and that of leucine yields acetyl-CoA and acetoacetate. Thus, valine is one of the glycogenic amino acids, but leucine is ketogenic, while isoleucine is both weakly glycogenic and weakly ketogenic.

In our previous experiment, ${ }^{2}{ }^{2}$ the metabolic fate of the carbon skeleton of leucine was examined by administering the ${ }^{14} \mathrm{C}$-labeled amino acid to growing rats fed with diets containing graded levels of dietary protein calories. It was found that, in protein-depleted rats, the expired ${ }^{14} \mathrm{CO}_{2}$ production was depressed and the utilization of this amino acid for body protein synthesis was increased. Subsequently, the metabolic response of the carbon skeleton of amino acids (alanine, glutamic acid, aspartic acid, serine, glycine, proline, arginine, tyrosine, phenylalanine, histidine and threonine) was also investigated. ${ }^{3 \sim 9)}$ In this experiment, the metabolism of valine and isoleucine are also examined in growing rats, in relation to nutritional data on the protein and energy metabolism, and compared to that of ${ }^{14} \mathrm{C}$-leucine or other amino acids previously tested.

\section{MATERIALS AND METHODS}

Animals and diets. Male Wistar rats weighing about $80 \mathrm{~g}$ were used in all experiments. The animals were maintained in a temperature-controlled room at $23 \pm 1^{\circ} \mathrm{C}$ with a $12 \mathrm{hr}$ 
light-12 hr dark cycle, and given food and water ad libitum for 10 days. The experimental diets contained $0,55,111$, 166 and $332 \mathrm{~g}$ of purified whole egg protein ${ }^{10}$ per $\mathrm{kg}$, as the $0,5,10,15$ and $30 \mathrm{PC} \%$ diets, respectively. All the diets contained $100 \mathrm{~g}$ of lard, $50 \mathrm{~g}$ of cellulose powder, $40 \mathrm{~g}$ of salt mixture, $10 \mathrm{~g}$ of vitamin mixture and enough corn starch to complete $1 \mathrm{~kg}$, as previously described. ${ }^{3)}$ The protein calorie percentage $(\mathrm{PC} \%$ ) means the proportion of of metabolizable energy of dietary protein to the total metabolizable energy of the diet, ${ }^{11}$ i.e., $4,100 \mathrm{kcal}$ per $\mathrm{kg}$ of diet in this experiment.

Isotope experiments. The amino acids injected were $\mathrm{L}-$ $\left[\mathrm{U}-{ }^{14} \mathrm{C}\right]$ valine $(290 \mathrm{mCi} / \mathrm{mmol})$ and $\mathrm{L}-\left[\mathrm{U}-{ }^{14} \mathrm{C}\right]$ isoleucine $(330 \mathrm{mCi} / \mathrm{mmol})$, which were purchased from the Radiochemical Center, Amersham. On the last day of feeding, the rats were starved for $9 \mathrm{hr}$, from 12:00 to $21: 00$, and then given the same experimental diets for $3 \mathrm{hr}$, from 21:00 to 24:00. After this feeding, ${ }^{14} \mathrm{C}$-valine or isoleucine in a saline solution was administered by intraperitoneal injection. The standard dosage was $1.83 \mu \mathrm{Ci} / 0.5 \mathrm{ml} / 100 \mathrm{~g}$ of body weight for ${ }^{14} \mathrm{C}$-valine and $3.27 \mu \mathrm{Ci}$ for ${ }^{14} \mathrm{C}$ isoleucine. Immediately after the injection, each animal was placed in a glass metabolism apparatus, and offered only water. The expired $\mathrm{CO}_{2}$ and urine were collected for $12 \mathrm{hr}$ and the radioactivities were determined as described previously. ${ }^{9}$

Analyses. The animals were killed by decapitation $12 \mathrm{hr}$ after administering the isotopes. The liver was removed, and the shed blood was combined with the carcass. The carcass and liver were homogenized and analyzed for the radioactivity of such major components as the protein, lipid and soluble fractions, the details of which were described in the previous paper. ${ }^{9)}$ A portion of the homogenates was extracted with a chloroform-methanol (C-M) mixture $(2: 1, v / v)^{12)}$ to obtain the lipid fraction, and the residue was then extracted with cold $10 \%$ trichloroacetic acid (TCA). The extract was combined with the upper phase solution by the Folch's washing method to obtain the soluble fraction of the sample. The TCA insoluble residue was dissolved in $2 \mathrm{~N} \mathrm{NaOH}$ as the protein fraction. The radioactivity of the lipid fraction was measured in a toluene scintillation solution containing $4 \mathrm{~g}$ of PPO and $0.5 \mathrm{~g}$ of POPOP per liter of toluene. The radioactivities of the protein and soluble fractions and the urine were measured in an NT scintillation solution containing $4 \mathrm{~g}$ of PPO per liter of 3 parts of nonylphenoxy polyethoxy ethanol and 7 parts of toluene. ${ }^{13}$ The radioactivity was measured with a liquid scintillation spectrometer (Packard, 3255). The efficiency of the counting system was estimated for each sample by an external standard ratio method.

The tissue protein was hydrolyzed with $6 \mathrm{~N} \mathrm{HCl}$ at $110^{\circ} \mathrm{C}$ for $24 \mathrm{hr}$ in a sealed tube. Amino acids in the hydrolysate were analyzed in an amino acid analyzer (JEOL, 6AHS). The effluent of the column was divided into two streams, the first one being used to detect the amino acids by the ninhydrin reaction and the second allowing the radioactivity to be determined.

Enzyme assays. At the end of the growth experiment for 10 days, the animals not injected with the isotopes were killed by decapitation. The liver, kidney and gastrocnemius muscles from one hind-limb were removed and immediately chilled. The tissue was homogenized with 9 volumes of ice-cold $0.1 \mathrm{M}$ sodium phosphate buffer in a Polytron homogenizer. The homogenate was centrifuged at $5,000 \times g$ for $15 \mathrm{~min}$ at $4^{\circ} \mathrm{C}$, and the supernatant was used for an assay of leucine aminotransferase by modifying the Ichihara and Koyama procedure. ${ }^{14}$ The reaction mixture contained $0.02 \mathrm{M}$ L-leucine, $0.5 \mathrm{~mm}$ pyridoxal-5'phosphate, $0.05 \mathrm{M} \alpha$-ketoglutarate, enzyme solution and $0.1 \mathrm{M}$ sodium phosphate buffer ( $\mathrm{pH} 8.6)$. The product, $\alpha-$ ketoisocaproate was determined with 2,4-dinitrophenylhydrazine. One unit of enzyme activity is defined as $1 \mu \mathrm{mol}$ of product formed per min, the activity of the enzyme being expressed as units per $100 \mathrm{~g}$ of body weight.

Statistical analysis. The results were tested by an analysis of variance, and Tukey's procedure for multiple comparisons was used to evaluate the statistical significance with a probability level of $0.05 .^{15)}$

\section{RESULTS}

The growth curve in the $0 \mathrm{PC} \%$ group was reduced, while that in the $5 \mathrm{PC} \%$ group was slightly retarded during the early days of the experimental period but began to increase gradually thereafter. The body weight gain reached its approximate maximum at around $10 \mathrm{PC} \%$ in the diet (Table I). The results of the growth experiments were essentially identical with those obtained in the previous experiments. ${ }^{3)}$

The total recovery percentages of ${ }^{14} \mathrm{C}$ in the $0,5,10,15$ and $30 \mathrm{PC} \%$ groups were $98,99,98$, 98 and $97 \%$, respectively, for valine, and 94 , $98,93,92$ and $96 \%$ for isoleucine (the means of four rats in each group).

As shown in Table II, the expired ${ }^{14} \mathrm{CO}_{2}$ production for $12 \mathrm{hr}$ after the injection of labeled valine was considerably less in the 0 $\mathrm{PC} \%$ diets, but it increased linearly with increasing dietary protein levels, about $40 \%$ of the injected dose being recovered in the 30 $\mathrm{PC} \%$ group. The expired ${ }^{14} \mathrm{CO}_{2}$ production from labeled isoleucine was depressed at 0 
and $5 \mathrm{PC} \%$, but it increased markedly at higher protein calories percentages with a break point close to $5 \mathrm{PC} \%$. The urinary excretion of radioactivity from valine or isoleucine was less than $3 \%$ of the injected dose.

Table I. Body Weight Gain and Liver Weight in Rats Fed with Diets of Various Dietary Protein Calorie Percentages

The values are mean \pm standard errors for eight rats. Tukey's test was taken as the criterion of statistical significance with a probability level of 0.05 .

\begin{tabular}{ccccc}
$\begin{array}{c}\text { Dietary } \\
\text { group } \\
(\mathrm{PC} \%)\end{array}$ & $\begin{array}{c}\text { Initial } \\
\text { body } \\
\text { weight } \\
(\mathrm{g})\end{array}$ & $\begin{array}{c}\text { Final } \\
\text { body } \\
\text { weight } \\
(\mathrm{g})\end{array}$ & $\begin{array}{c}\text { Gain } \\
(\mathrm{g} / \text { day })\end{array}$ & $\begin{array}{c}\text { Liver } \\
\text { weight } \\
(\mathrm{g})\end{array}$ \\
\hline 0 & $80 \pm 3$ & $68 \pm 3$ & $-1.2 \pm 0.1$ & $2.5 \pm 0.2$ \\
5 & $79 \pm 3$ & $117 \pm 5$ & $3.7 \pm 0.3$ & $4.1 \pm 0.2$ \\
10 & $77 \pm 3$ & $152 \pm 3$ & $7.4 \pm 2.3$ & $5.2 \pm 0.2$ \\
15 & $78 \pm 3$ & $157 \pm 5$ & $7.9 \pm 0.2$ & $5.2 \pm 0.2$ \\
30 & $78 \pm 3$ & $147 \pm 4$ & $7.0 \pm 0.2$ & $5.0 \pm 0.2$ \\
\hline Difference & - & 16 & 2.4 & 1.6 \\
$(p<0.05)$ & & & & \\
\hline
\end{tabular}

The value in the low protein groups was reduced, but was significantly increased in the higher $\mathrm{PC} \%$ groups. The distribution of radio-

TABLe II. Recovery OF ${ }^{14} \mathrm{C}$ IN EXPIREd $\mathrm{CO}_{2}$ AND URINE FROM L- $\left[\mathrm{U}-{ }^{14} \mathrm{C}\right]$ VALINE AND L-[U- $\left.{ }^{14} \mathrm{C}\right]-$ ISOLEUCINE IN RATS FED WITH DIETS OF Various Dietary Protein Calorie Percentages

The values are mean \pm standard errors for four rats. Tukey's test was taken as the criterion of statistical significance with a probability level of 0.05 .

\begin{tabular}{|c|c|c|c|c|}
\hline \multirow{2}{*}{$\begin{array}{c}\text { Dietary } \\
\text { group } \\
(\mathrm{PC} / \mathrm{s})\end{array}$} & \multicolumn{2}{|c|}{${ }^{14} \mathrm{C}$-Valine } & \multicolumn{2}{|c|}{${ }^{14} \mathrm{C}$-Isoleucine } \\
\hline & $\mathrm{CO}_{2}$ & Urine & $\mathrm{CO}_{2}$ & Urine \\
\hline \multicolumn{5}{|c|}{$(\%$ of the injected dose $)$} \\
\hline 0 & $6.5 \pm 0.5$ & $0.7 \pm 0.1$ & $7.8 \pm 1.3$ & $0.5 \pm 0.1$ \\
\hline 5 & $11.0 \pm 0.4$ & $0.7 \pm 0.04$ & $9.3 \pm 0.5$ & $0.5 \pm 0.01$ \\
\hline 10 & $15.6 \pm 0.6$ & $0.8 \pm 0.02$ & $16.5 \pm 1.6$ & $0.5 \pm 0.02$ \\
\hline 15 & $23.2 \pm 1.4$ & $1.6 \pm 0.7$ & $22.7 \pm 0.7$ & $0.7 \pm 0.01$ \\
\hline 30 & $39.3 \pm 1.7$ & $2.3 \pm 0.2$ & $43.1 \pm 2.9$ & $1.8 \pm 0.1$ \\
\hline $\begin{array}{l}\text { Difference } \\
(p<0.05)\end{array}$ & 4.9 & 1.6 & 7.2 & 0.3 \\
\hline
\end{tabular}

Table III. Recovery of ${ }^{14}$ C-Radioactivity in the Protein, Lipid and Soluble Fractions of Carcass and Liver from L-[U- $\left.-{ }^{14} \mathrm{C}\right]$ Valine and L- $\left[\mathrm{U}-{ }^{14} \mathrm{C}\right]$ Isoleucine in Rats Fed with Diets of Various Dietary Protein Calorie Percentages

The values are mean \pm standard errors for four rats. Tukey's test was taken as the criterion of statistical significance with a probability level of 0.05 .

\begin{tabular}{|c|c|c|c|c|c|c|}
\hline \multirow{2}{*}{$\begin{array}{c}\text { Dietary } \\
\text { group } \\
\left(\mathrm{PC}^{\circ}\right)\end{array}$} & \multicolumn{2}{|c|}{ Protein } & \multicolumn{2}{|c|}{ Lipid } & \multicolumn{2}{|c|}{ Soluble fraction } \\
\hline & Carcass & Liver & Carcass & Liver & Carcass & Liver \\
\hline & \multicolumn{6}{|c|}{$(\%$ of the injected dose $)$} \\
\hline \multicolumn{7}{|l|}{${ }^{14} \mathrm{C}$-Valine } \\
\hline 0 & $71.8 \pm 2.0$ & $9.4 \pm 0.6$ & $1.1 \pm 0.1$ & $0.03 \pm 0.003$ & $6.6 \pm 0.2$ & $0.3 \pm 0.02$ \\
\hline 5 & $74.0 \pm 0.9$ & $7.3 \pm 0.2$ & $1.3 \pm 0.1$ & $0.05 \pm 0.01$ & $4.4 \pm 0.2$ & $0.3 \pm 0.01$ \\
\hline 10 & $68.1 \pm 2.1$ & $7.5 \pm 0.4$ & $1.6 \pm 0.04$ & $0.05 \pm 0.01$ & $4.1 \pm 0.1$ & $0.4 \pm 0.02$ \\
\hline 15 & $59.8 \pm 2.5$ & $6.2 \pm 0.2$ & $1.7 \pm 0.05$ & $0.07 \pm 0.01$ & $4.3 \pm 0.3$ & $0.5 \pm 0.08$ \\
\hline 30 & $46.0 \pm 1.7$ & $4.1 \pm 0.1$ & $1.7 \pm 0.03$ & $0.08 \pm 0.01$ & $3.6 \pm 0.2$ & $0.5 \pm 0.11$ \\
\hline $\begin{array}{c}\text { Difference } \\
(p<0.05)\end{array}$ & 8.3 & 1.5 & 0.3 & 0.03 & 1.0 & - \\
\hline \multicolumn{7}{|c|}{${ }^{14} \mathrm{C}$-Isoleucine } \\
\hline 0 & $67.5 \pm 1.7$ & $10.2 \pm 1.1$ & $1.7 \pm 0.2$ & $0.06 \pm 0.01$ & $5.0 \pm 0.4$ & $0.2 \pm 0.01$ \\
\hline 5 & $74.2 \pm 2.1$ & $8.3 \pm 0.4$ & $2.1 \pm 0.1$ & $0.07 \pm 0.01$ & $3.3 \pm 0.2$ & $0.2 \pm 0.02$ \\
\hline 10 & $63.1 \pm 1.5$ & $7.0 \pm 0.02$ & $2.7 \pm 0.2$ & $0.08 \pm 0.01$ & $2.8 \pm 0.1$ & $0.2+0.02$ \\
\hline 15 & $57.0 \pm 0.9$ & $5.4 \pm 0.2$ & $2.7 \pm 0.1$ & $0.10 \pm 0.01$ & $3.0 \pm 0.2$ & $0.2 \pm 0.08$ \\
\hline 30 & $38.6 \pm 3.7$ & $3.5 \pm 0.7$ & $3.9 \pm 0.4$ & $1.25 \pm 0.06$ & $3.4 \pm 0.3$ & $1.0 \pm 0.45$ \\
\hline $\begin{array}{c}\text { Difference } \\
(p<0.05)\end{array}$ & 9.6 & 2.6 & 1.0 & 0.12 & 1.0 & 0.8 \\
\hline
\end{tabular}


activity in the protein, lipid and soluble fractions of the carcass and liver is shown in Table III. The incorporation of radioactivity into the carcass protein from labeled valine or isoleucine was most increased in the 0 and $5 \mathrm{PC} \%$ groups (about $70 \%$ of the dose), but it was decreased in the higher $\mathrm{PC} \%$ groups. The values for liver protein from both valine and isoleucine were also high in the $0 \mathrm{PC} \%$ group, and gradually decreased with increasing the dietary protein levels. The conversion of ${ }^{14} \mathrm{C}$ from valine into the carcass and liver lipid was less than that from isoleucine over the whole range of dietary groups tested, and the value for isoleucine was markedly increased in the higher $\mathrm{PC} \%$ groups. About 5 to $7 \%$ of the injected dose was recovered in the carcass soluble fraction for both the amino acids in the $0 \mathrm{PC} \%$ group.

The distribution of radioactivity in each amino acid fraction after hydrolyzing the carcass and liver protein was examined in the 10 $\mathrm{PC} \%$ group for both valine and isoleucine (Fig. 1). As for ${ }^{14} \mathrm{C}$-valine, a high level of radioactivity was only detected in the valine fraction, and negligible levels of radioactivity were detected in all other amino acid fractions. As for ${ }^{14} \mathrm{C}$-isoleucine, a large peak of radioactivity was associated with the isoleucine fraction, but a minor unknown peak was present at the top of this large peak. The elution pattern from the carcass protein hydrolysate was similar to that from the liver protein hydrolysate in both the case of valine and isoleucine.

The activity of leucine aminotransferase, as a typical example of the enzymes transaminating the branched chain amino acids, was measured in various tissues of rats (Table IV). Liver showed the lowest activity of leucine aminotransferase, followed by kidney, and skeletal muscle showed the highest activity. The total activity in the hepatic aminotransferase was depressed in the $0 \mathrm{PC} \%$ group and increased at $30 \mathrm{PC} \%$, while no significant change in the activity of this enzyme was observed in kidney. Moreover, the enzyme activity in skeletal muscle was high in protein

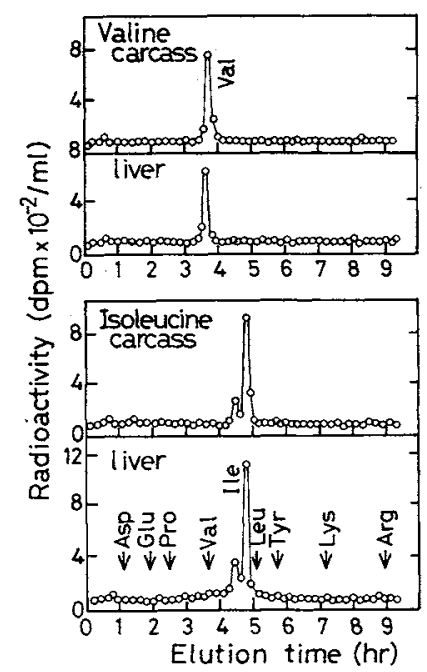

FIG. 1. Distribution of Radioactivity in Each Amino Acid Fraction from Carcass and Liver Protein Hydrolysates after Injecting $\mathrm{L}-\left[\mathrm{U}-{ }^{14} \mathrm{C}\right]$ Valine or $\mathrm{L}-[\mathrm{U}$ $\left.{ }^{14} \mathrm{C}\right]$ Isoleucine in Rats Fed with the $10 \mathrm{PC} \%$ Diet.

An amino acid analysis was carried out in an automatic amino acid analyzer using a lithium citrate buffer system. In the ${ }^{14} \mathrm{C}$-valine experiment, $4 \mathrm{ml}$ fractions were collected during 0 to $3 \mathrm{hr}, 2 \mathrm{ml}$ during 3 to $4 \mathrm{hr}$, and $4 \mathrm{ml}$ during 4 to $10 \mathrm{hr}$. In the ${ }^{14} \mathrm{C}$-isoleucine experiment, $4 \mathrm{ml}$ fractions were collected during 0 to $4 \mathrm{hr}, 1 \mathrm{ml}$ during 4 to $5 \mathrm{hr}$, and $4 \mathrm{ml}$ during 5 to $10 \mathrm{hr}$. Aliquots of each fraction were taken for the measurement of radioactivity.

Table IV. Leucine Aminotransferase Activity in Liver, Kidney and Skeletal Muscle of Rats Fed with Diets of Various Dietary Protein Galorie Percentages

The values are mean \pm standard errors for four rats. Tukey's test was taken as the criterion of statistical significance with a probability level of 0.05 .

\begin{tabular}{cccc}
$\begin{array}{c}\text { Dietary } \\
\text { group } \\
(\mathrm{PC} \%)\end{array}$ & Liver & Kidney & $\begin{array}{c}\text { Skeletal } \\
\text { muscle* }\end{array}$ \\
\hline & & & \\
\hline & $(\mathrm{U} / 100 \mathrm{~g}$ body weight $)$ \\
5 & $0.39 \pm 0.07$ & $2.3 \pm 0.2$ & $26.6 \pm 1.9$ \\
10 & $0.63 \pm 0.04$ & $2.2 \pm 0.2$ & $24.9 \pm 1.6$ \\
15 & $0.59 \pm 0.06$ & $1.8 \pm 0.1$ & $20.3 \pm 1.8$ \\
30 & $0.84 \pm 0.06$ & $1.9 \pm 0.1$ & $13.0 \pm 2.1$ \\
\hline $\begin{array}{c}\text { Difference } \\
(p<0.05)\end{array}$ & 0.23 & - & 9.5 \\
\hline
\end{tabular}

* The assumption is made that skeletal muscle was $31.5,36.0$ and $40.5 \%$ of body weight for rats weighing 50,100 and $150 \mathrm{~g}$, respectively. ${ }^{22)}$ 
depletion and reduced in the $30 \mathrm{PC} \%$ group. When the activity of the enzyme in skeletal muscle is expressed as the specific activity ( $\mathrm{U} / \mathrm{mg}$ protein), a similar response curve to that for dietary protein intake was also obtained.

\section{DISCUSSION}

The metabolic fate of the carbon skeletons of amino acids can be grouped into three major categories: a) synthesis of protein; b) synthesis of smaller molecules such as purine and creatinine; and c) degradative reactions, in which the carbon skeletons are removed as $\mathrm{CO}_{2}$ or deposited as lipid or carbohydrate in the tissue. ${ }^{16)}$

This study aimed at investigating the metabolic fate of individual amino acids in the bodies of growing rats at various dietary protein calorie percentages. In our series of studies, ${ }^{3 \sim 9)}$ it was found that the majority of ${ }^{14} \mathrm{C}$-alanine, glutamic acid or aspartic acid was rapidly oxidized to expired carbon dioxide, while a large amount of ${ }^{14} \mathrm{C}$-leucine, threonine, histidine, phenylalanine, tyrosine or arginine was utilized for body protein synthesis, and that the carbon skeleton of glycine, serine or proline was preferentially utilized for body protein synthesis rather than for energy production. In this experiment, the metabolic fate of the carbon skeletons of ${ }^{14} \mathrm{C}$-valine and isoleucine was subsequently examined. The gross distribution of radioactivity in the body protein and expired ${ }^{14} \mathrm{CO}_{2}$ from labeled valine and isoleucine is summarized in Fig. 2, comparing with the results obtained previously for labeled leucine. ${ }^{2)}$ The value for body protein was calculated as the total for carcass and liver. The results suggest that these three branched-chain amino acids were preferentially utilized for body protein synthesis, especially with low-protein intakes. Although similar response curves to dietary protein intake for the ${ }^{14} \mathrm{C}$ incorporation into body protein were obtained, the pattern of expired ${ }^{14} \mathrm{CO}_{2}$ production from labeled valine was some-

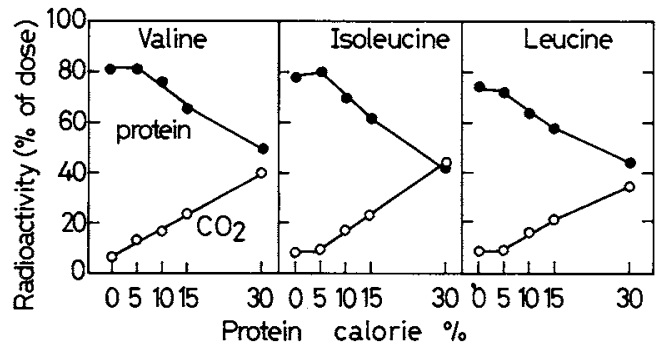

Fig. 2. Incorporation of the ${ }^{14} \mathrm{C}$ into Body Protein and Expired ${ }^{14} \mathrm{CO}_{2}$ Production from ${ }^{14} \mathrm{C}$-Labeled Branched Chain Amino Acids in Rats Fed with Diets of Various Protein Calorie Percentages.

Each point is the mean for three to four rats. protein; $\mathrm{O}-\mathrm{O}$, expired $\mathrm{CO}_{2}$.

what differed from that from isoleucine or leucine. The expired ${ }^{14} \mathrm{CO}_{2}$ production from valine was linearly increased with increasing dietary protein levels, whereas that from isoleucine or leucine was depressed in the proteindepleted rats and elevated from above $10 \mathrm{PC} \%$ in the diet. The carbon skeleton of the essential amino acids examined so far was conserved in the protein-depleted rats, and its oxidative degradation began to increase when the dietary supply exceeded the optimal level, but this was not so for valine. It is unlikely that the linear output of ${ }^{14} \mathrm{CO}_{2}$ for valine was due to ingestion of a diet containing a disproportionate (excessive) amount of valine as compared to leucine or isoleucine, when considering the amino acid composition of the purified whole egg protein and the requirement levels of these amino acids for growing rats. Sketcher et al. ${ }^{17)}$ and MacFarlane and von Holt ${ }^{18)}$ have also found a marked decrease in the expired ${ }^{14} \mathrm{CO}_{2}$ production from labeled leucine in protein depletion. However, Neale and Waterlow $^{19)}$ and Reeds ${ }^{20)}$ reported that there was no difference in the output of ${ }^{14} \mathrm{CO}_{2}$ from labeled leucine and valine, when the rats adapted to a protein-free diet were compared with those on the control diet, and that the oxidation of $\left[\mathrm{U}^{-14} \mathrm{C}\right]$ valine in vivo was not reduce in rats given a low-protein diet, although $\left[1-{ }^{14} \mathrm{C}\right]$ valine oxidation was reduced by $40 \%$ in these animals. These discrepancies cannot be resolved at the present time. As shown in Fig. 


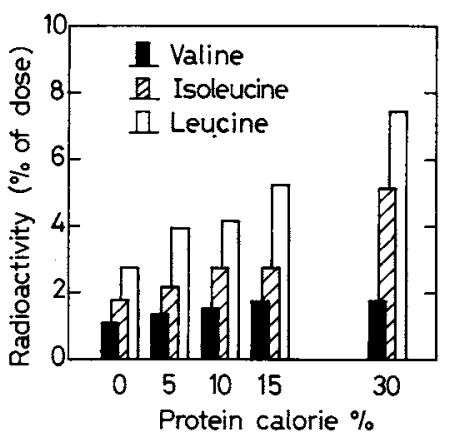

FIG. 3. Conversion of the Carbon Skeleton of Branched Chain Amino Acids to Body Lipid in Rats Fed with Diets of Various Protein Calorie Percentages.

Each value represents the mean for three to four rats.

3, on the other hand, the conversion of the carbon skeletons of branched-chain amino acids into body lipid (carcass plus liver) was less than $8 \%$ of the injected dose, and was gradually increased by increasing the dietary protein level. Since acetoacetate and acetyl$\mathrm{CoA}$ are products of the leucine catabolic pathway and are potential precursors of fatty acid and cholesterol, it would be reasonable for the conversion of leucine carbon into lipids to be the greatest among these three amino acids, followed by isoleucine which produces acetyl-CoA and succinyl-CoA. The conversion of valine carbon into lipids was much less than leucine and isoleucine, because this amino acid would be degraded to succinyl-CoA and show a glycogenic property. Thus, these branched chain amino acids are primarily utilized for body protein synthesis, and when an excess is supplied, their carbon skeletons are oxidized to carbon dioxide or converted to fat for energy metabolism.

Ichihara and Koyama ${ }^{14)}$ reported that the branched chain amino acids were all transaminated by the same enzyme in various tissues of rats. Featherston and $\operatorname{Horn}^{21)}$ also found a similar response for the aminotransferase activities when valine, isoleucine or leucine was used as the substrate. Thus, most of the studies suggest a single enzyme for transamination of all three branched-chain amino acids, so that we measured the activity of leucine aminotransferase as a typical example of the trans- amination of these three amino acids. It is known that, because of a higher activity of the enzyme in skeletal muscle and kidney rather than in liver, the distribution of this enzyme in various tissues is different from most other aminotransferases. Our observation for the tissue distribution of this enzyme (Table IV) agreed well with the previous findings. Mimura et al. ${ }^{22)}$ and Sketcher et al. ${ }^{17)}$ demonstrated an increase in the activity of this enzyme in the skeletal muscle of rats fed with a protein-free diet. In this experiment, a slight increase in the enzyme activity (both specific and total) was also observed in the $0 \mathrm{PC} \%$ group, and a marked decrease in the $30 \mathrm{PC} \%$ group. Thus, the change in the activity of aminotransferase in muscle was not parallel to the oxidative degradation of these ${ }^{14} \mathrm{C}$-amino acids. This phenomenon may suggest that the changes in enzyme activity as measured in vitro are not necessarily associated with the quantitative metabolic changes in vivo. Probably, the changes in the expired ${ }^{14} \mathrm{CO}_{2}$ production from branched-chain amino acids may be attributed to the supply of substrate.

Acknowledgments. The authors express their sincere thanks to Professor H. Nishi for his interest and support in this study. The authors are also indebted to Dr. M. Yamaguchi of the National Institute of Nutrition for his suggestions.

\section{REFERENCES}

1) V. R. Young, "Mammalian Protein Metabolism," Vol. IV, ed. by H. N. Munro, Academic Press, New York and London, 1970, p. 612.

2) H. Tanaka, M. Yamaguchi and M: Kametaka, Agric. Biol. Chem., 39, 507 (1975).

3) H. Tanaka, M. Yamaguchi and M. Kametaka, Agric. Biol. Chem., 38, 1113 (1974).

4) H. Tanaka, M. Yamaguchi and M. Kametaka, Agric. Biol. Chem., 40, 1119 (1976).

5) H. Tanaka and M. Ogura, Agric. Biol. Chem., 44, 9 (1980).

6) H. Tanaka and M. Ogura, Agric. Biol. Chem., 44; $2343(1980)$.

7) H. Tanaka and M. Ogura, Agric. Biol. Chem., 48, 2731 (1984).

8) H. Tanaka, Y. Nakatomi and M. Ogura, Agric. Biol. Chem., 51, 499 (1987). 
9) H. Tanaka, Y. Nakatomi and M. Ogura, Agric. Biol. Chem., 51, 3087 (1987).

10) M. Yamaguchi and M. Kandatsu, Agric. Biol. Chem., 37, 809 (1973)

11) D. S. Miller and P. R. Payne, Brit. J. Nutr., 15, 11 (1961)

12) J. Folch, M. Lee and G. H. Sloane-Stanley, J. Biol. Chem., 226, 497 (1957)

13) M. Kawakami and K. Shimura, Radioisotopes, 23, 15 (1972)

14) A. Ichihara and E. Koyama, J. Biochem., 59, 160 (1966).

15) M. Yoshida, "Design of Experiments of Animal Husbandry," Yokendo Co., Tokyo, 1975, p. 84.

16) H. N. Munro, "Mammalian Protein Metabolism,"
Vol. IV, ed. by H. N. Munro, Academic Press, New York and London, 1970, p. 101.

17) R. D. Sketcher, E. B. Fern and W. P. T. James, Brit. J. Nutr., 31, 333 (1974).

18) I. G. MacFarlane and C. von Holt, Biochem. J., 111, 557 (1969).

19) R. J. Neale and J. C. Waterlow, Brit. J. Nutr., 32, 11 (1974).

20) P. Reeds, Brit. J. Nutr., 31, 259 (1974).

21) W. P. Featherston and G. W. Horn, J. Nutr, 103, 757 (1973).

22) S. A. Miller, "Mammalian Protein Metabolism," Vol. III, ed. by H. N. Munro, Academic Press, New York and London, 1969, p. 188. 